\title{
Effects of interference with GATA-3 expression by target-specific DNAzyme treatment on disease progression in a subacute oxazolone-induced mouse model of atopic dermatitis
}

\author{
Rouba Ibrahim ${ }^{1}$, Ulrich Purath ${ }^{2 *}$, Agnieszka Turowska ${ }^{2}$, Ursula Homburg $^{2}$, Frank Runkel ${ }^{3}$, Thomas Schmidts ${ }^{3}$, \\ Dorota Dobler ${ }^{3}$, Harald Renz' ${ }^{1}$, Holger Garn', Anke Mueller ${ }^{2}$
}

From EAACI Skin Allergy Meeting 2014

Krakow, Poland. 18-20 September 2014

\section{Background}

DNAzymes represent a particular class of antisense molecules combining the specificity of antisense molecules with an inherent catalytic cleavage activity, which makes them an attractive tool for highly specific interference with target RNA molecules. In general, they are single-stranded DNA molecules with sequence-specific RNA-binding domains flanking a central catalytic domain. We developed and patented a DNAzyme - named hgd 40 - that targets the mRNA for GATA-3, the central transcription factor in T helper cell type 2 (Th2) differentiation and activation. For penetration enhancement and DNAzyme protection a specific water/oil/water emulsion for topical dermal application was developed and patented. Targeting GATA-3 might be a key for therapeutic intervention in predominantly Th2-driven diseases like atopic dermatitis.

\section{Method}

The therapeutic effects of hgd40 were analyzed in an oxazolone-induced dermatitis model modified to establish elongated skin swelling reactions, thereby enabling the analysis of treatment effects on T cell-mediated pathomechanisms.

\section{Results}

Treatment with topically applied hgd40 water/oil/water emulsion significantly and dose-dependently reduced oxazolone-induced skinfold thickness and suppressed infiltration of $\mathrm{CD} 4+\mathrm{T}$ cells into the skin. Molecular analysis

${ }^{2}$ sterna biologicals, ZTI, Marburg, Germany

Full list of author information is available at the end of the article revealed reduced GATA-3 mRNA levels early during disease progression.

\section{Conclusion}

In summary, targeting GATA-3 by DNAzyme treatment may represent a new and promising therapeutic agent for the topical treatment of allergic skin diseases.

\section{Authors' details}

'Philipps University of Marburg, Inst. of Laboratory Medicine and Pathobiochemistry, Marburg, Germany. ${ }^{2}$ sterna biologicals, ZTI, Marburg, Germany. ${ }^{3}$ University of Applied Sciences, IBPT, Giessen, Germany.

Published: 11 March 2015

doi:10.1186/2045-7022-5-S1-O21

Cite this article as: Ibrahim et al:: Effects of interference with GATA-3 expression by target-specific DNAzyme treatment on disease progression in a subacute oxazolone-induced mouse model of atopic dermatitis. Clinical and Translational Allergy 2015 5(Suppl 1):021.

Submit your next manuscript to BioMed Central and take full advantage of:

- Convenient online submission

- Thorough peer review

- No space constraints or color figure charges

- Immediate publication on acceptance

- Inclusion in PubMed, CAS, Scopus and Google Scholar

- Research which is freely available for redistribution 